\title{
Reflections on Leadership and Career Development
}

Book Review

\author{
Author: Manfred F.R. Kets de Vries \\ Reviewed by: Shiva Kumar Srinivasan \\ IIPM, Chennai, India \\ shiva.srinivasan@iipm.edu
}

\begin{abstract}
What does psychoanalysis have to teach us about the theory and practice of leadership? How can these insights, if any, be leveraged to develop careers systematically? What, more specifically, is the role that the behavioural sciences, or the 'clinical approach' to leadership coaching, can play in the formation of management professionals? These then are the governing set of questions which Kets de Vries addresses in this book. All these questions however are in the service of an even more fundamental problem: How can leaders learn to be 'decisive' without 'acting-out' repressed conflicts (of which they are unconscious) in the symbolic realm? The preoccupation with 'reflection' in this literature then is an attempt to coach leaders in executive development programmes to pose existential questions at periodic intervals without hurtling into the future in a mindless fashion. This was the danger that Kets de Vries had caricatured much earlier in his career under the aegis of the title 'life and death in the executive fast lane' for individual executives, and the 'neurotic organization' to delineate the irrational behaviour of firms. The main takeaway in these studies is that whole organizations can act-out like leaders. The only difference is that in the case of organizations, the pressure to do so comes from the anxieties or insecurities experienced by the 'dominant coalition' in a firm. But, whatever may be the affective sources of acting out, the effect is the same. It creates a mess which will become increasingly difficult to clean up for those in charge. It is therefore a good idea for leaders to set up socio-cultural mechanisms that will help to discharge affects periodically without destabilizing the organization.
\end{abstract}

The idea that the quality of governance can improve the emotional health of an organization or conversely that the emotional health of an organization(especially of its dominant coalition) will eventually improve the quality of its governance mechanisms then is the theoretical ideal that the INSEAD School of Organizational Psychology has been pushing relentlessly for a number of years. There is needless to say a problem of what is 'cause' and what is 'effect' here since it appears that in practice either could be the cause or the effect given the theoretical propensity to invoke models of 'reverse causation' in psychoanalysis. The adjective that best captures this ideal is termed 'authentizotic' (i.e. an organization where employees feel 'psychologically safe' to be themselves, and can therefore pursue the goal of being 'authentic' in their interactions with colleagues and customers). This ideal and the question of its 'possibility' or 'impossibility' as a set of modalities that can be actually operationalized is however not a problem of Freudian metapsychology for them, but a pragmatic set of questions that can be workedthrough in executive coaching and management development programmes. It is important to understand this clearly since Sigmund Freud himself felt that there was something inherently impossible in psychoanalysis as a profession, and had done some important pioneering work on group psychology before concluding that the three 'impossible professions' for him were psychoanalysis, education, and governance. Strangely enough, these are precisely the areas in which Kets de Vries is determined to make progress without allowing his attempts to be derailed by the difficulties involved in doing so. Another way of looking at this ideal then is to situate it quite simply as the latest incarnation of the ancient Greek ideal of 'Know Thy self' (applied albeit to the context of management education).

The executive coach fashions his professional identity not only on the psychotherapeutic professions, but is, more fundamentally, preoccupied with Socratic midwifery in the realm of the coagulated affects and ideas that hold executives in their grip. The Socratic ethic of psychoanalysis and allied professions then is what is at stake in the existential challenge of self-reflection. The reality check for executive coaches and coaches when they interact is this: Will they be able to incorporate the need for periodic reflection as an ethical ideal in their notion of leadership practice? It is not necessarily the case here that the notion of reflection must take on the magnitude of a 'Stoic ideal' in an executive's psyche. It will suffice if it at least helps him to identify, name, and work-through counter-transferential affects when he interacts with his subordinates or followers so that he is able to live the 'examined life' in however modest a way: hence the interest that Kets de Vries continually evinces in Zen narratives given their implications for the 
pedagogical and psychotherapeutic process. The goal for executives and leaders then is the need to act decisively without acting-out. An important takeaway here is that attempts to teach decision making in business schools must recognize the range of affects that colour the process of so-called rational decision making, especially when executives are under pressures created by anxiety, stress, and looming deadlines.

There are three parts to this book. The main themes covered here comprise the psychology of leadership, the personality of leaders, and the relationship between leadership and career development in organizations. The first part examines the transferential dynamics of leadership comprising questions such as: Why are there leaders at all? What psychological needs in followers are addressed by leaders? What are the challenges of the counter-transference on the part of leaders? In what ways, if any, do leaders become dependent on their followers? These questions are quite similar to how situations of 'codependency' play out in clinical dynamics. Kets de Vries uses, whenever possible, the affective relationship between psychoanalysts and patients to model the relationship between leaders and followers. An important question that is worked-through in psychoanalysis is the 'irreducibility of narcissism' in the psyche. It is therefore important to ask what sort of 'kick' leaders get out of having followers and how they cope when the next generation of leaders make a claim to the throne. These questions are also analogues to the 'end of analysis' problem in Freudian metapsychology. What sorts of demands are made by analysts and patients when they negotiate the end of a therapeutic relationship? Can they let go of each other and be honest about the forms of mutual dependence that constitute their relationship? Or will they let their relationship degenerate into mutual accusations of who needs whom more? These are but a sample of the existential dilemmas that leaders and followers have to workthrough if they aspire to a mature resolution of their previous encounters. Kets de Vries alerts readers to the fact that transferential dynamics involves the repetition of infantile prototypes from the Oedipal phase, and must therefore be negotiated with a lot of tact by both analysts and patients. Likewise, it is important for leaders and followers to understand the forms of psychic repetition that they are vulnerable to if they are to avoid the temptations of acting out.

The second part profiles the career of Russian leader Vladimir Putin and tries to analyse why and how he consolidated his hold on post-Communist Russia. The basic problem in the profile is the paucity of information on Russian leaders in general and Putin in particular. Kets de Vries did not interview Putin in person, but tries to situate him within a range of psychological themes that constitute Russian approaches to leadership like the need to embody sobriety, heroism, and strength given the drunken excesses of his predecessor Boris Yeltsin and the traumatic interlude of the coup against Mikhail Gorbachev. The partnership between Vladmir Putin and Dmitry Medvedev is also taken up, but the profile does not examine at length how they managed to make their relationship work out so well. Most of the enigmas of Russia continue to remain enigmas, and while this profile is quite readable for those interested in Russian politics, it is not as psychoanalytic in its approach as readers might want it to be. Why Russian leaders resist psychoanalytic interpretation or explanation in the way that Anglo-American leaders do not is yet another problem of psychohistory that Kets de Vries and his associate Konstanin Korotov might consider addressing at length elsewhere. This is all the more important given the interest that the INSEAD theorists have in understanding the cognitive and psychic styles of Russian leadership in both business and politics. Kets de Vries also works out a typology of complexes that executives are subject to including 'the God complex, the Sisyphus complex, the Nobel Prize complex, the Monte Cristo complex, the Troll complex, and the Faust complex', and the ways in which they cope with these complexes. And, again, given his eclecticism, Kets de Vries is not exactly averse to the idea of leadership archetypes including those of 'the strategist, the change catalyst, the transactor, the builder, the innovator, the processor, the coach, and the communicator'. Unlike a Jungian analyst, for instance, Kets de Vries is not interested in typologies as an end in itself, but uses it as a platform to advice readers on how they should communicate with and/or understand the behaviour of leaders within a typology of archetypes. This is the advisory approach that Kets de Vries uses to find a pragmatic resolution on a range of questions without invoking the problem of the impossible or losing his way in formalizing the sources of the personal or the collective unconscious.

The third and final part of the book is an attempt to work-through the ethical necessity of 'letting go' in the life of executives who have a strong materialistic orientation as a necessary defence to attain a high level of competitiveness. When career trajectories are interrupted however they are forced to come to terms with problems like a mid-life crisis, declining health, and a sense of drift and meaninglessness. These are incidentally the themes that are rehearsed in the end of analysis problem where the patient 
must come to terms with the loneliness inherent in the realization that the analyst cannot accompany him all the way to the grave, and no amount of analysis will cure the problem of human mortality. The ethical ideal then is not to evade death somehow, but come to terms existentially with death as an endless preoccupation in the psyche. The so-called 'retirement neurosis', for instance, is just a defence against deeper concerns such as the fear of death and the need to take stock on whether a particular life was indeed worth living in the context of a particular value system. Kets de Vries alludes to an idea that William James, the Harvard psychologist, invoked to cope with this trauma. James believed that some people are 'twice born' insofar as they can turn a crisis around existentially by deepening their receptivity to what life still has to offer them. These twice born individuals experience life more deeply than the 'living dead' who are not open to any deeply felt emotion since they feel that what must be behind any deeply felt emotion is the abyss which might swallow them up. The ethical ideal of the examined or the analysed life is to muster the courage to be open to precisely this moment of momentary rebirth before accepting the abyss of death for what it is. That is the final triumph of an authentic opening up to the beyond of human existence which psychoanalysis or clinical approaches can imbue as early as possible in executives through the process of leadership coaching. Leadership and career development for Kets de Vries then is not about a world where everybody competes furiously to become the CEO, but where at least a few executives will have the courage to live out their lives and careers with as few symptoms and psychic defences as possible. 